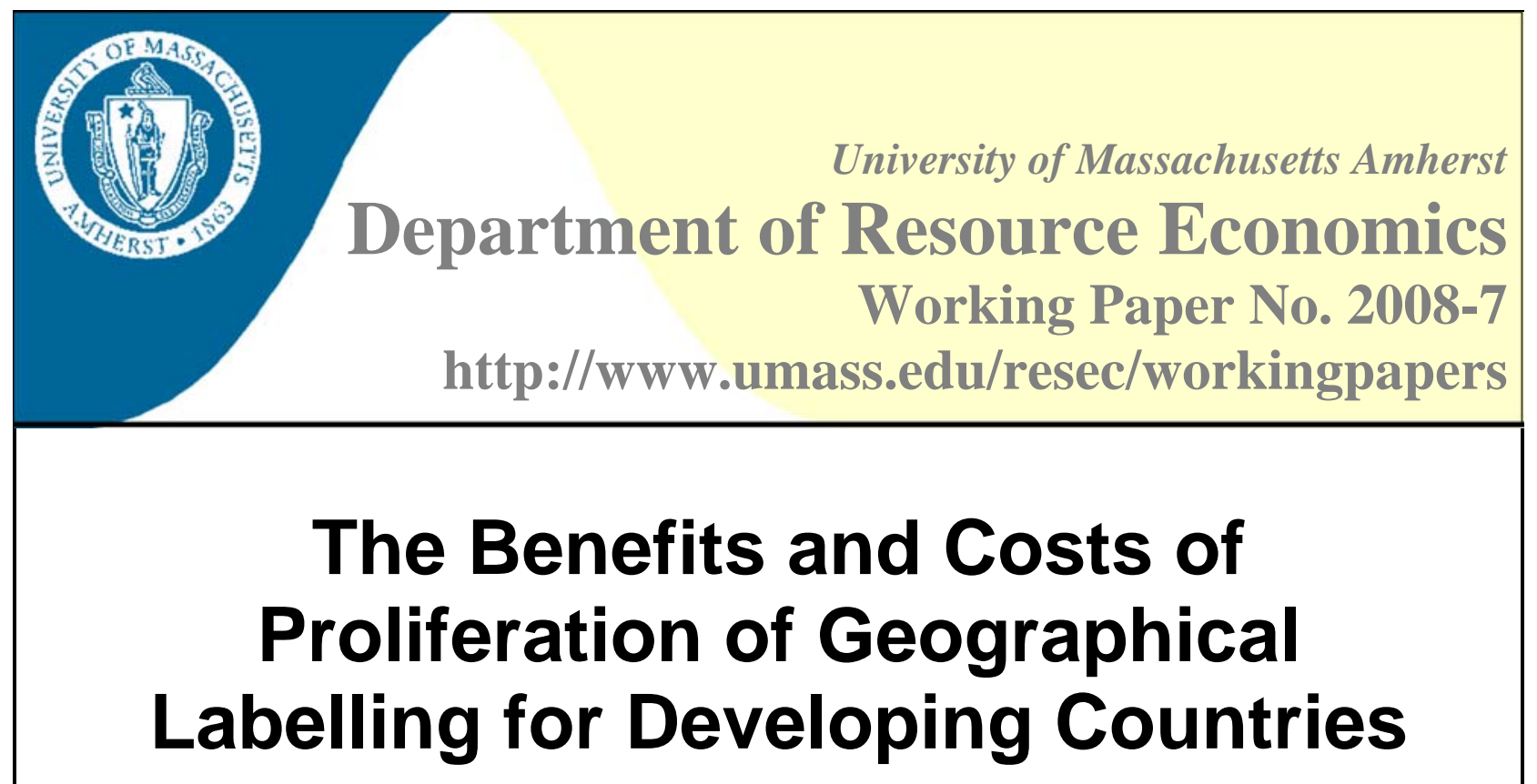

Sven Anders ${ }^{1}$ and Julie A. Caswell ${ }^{2}$

Abstract:

Food product attributes related to geographical origins are a topical issue in global food trade. The provision of geographical labelling may occur through geographical indications under the mandated trade rules of the TRIPS Agreement, trademarks, or country-of-origin labelling. The overall effect of the expansion of geographical labelling on developing countries depends on a complex mix of market opportunities that may yield substantial benefits as well as implementation costs. Increasingly, the analysis of this overall effect will need to evaluate the joint impacts of different forms of geographical labelling on the market position of developing countries.

Keywords: developing countries, geographical labelling, international trade, TRIPS

JEL Classification: F13, Q13, O19

\footnotetext{
${ }^{1}$ Sven Anders, Department of Rural Economy

University of Alberta

Edmonton Alberta T6G 2H1, Canada

E: sven.anders@ualberta.ca P: +1 7804925453 F: +1 7804920268

${ }^{2}$ Julie A. Caswell, Department of Resource Economics

University of Massachusetts, 215 Stockbridge Hall

80 Campus Center Way, Amherst, MA 01003

E: caswell@resecon.umass.edu P: 413-545-5735 F: 413-545-5853
} 


\title{
The Benefits and Costs of Proliferation of Geographical Labelling for Developing Countries
}

by

Sven Anders and Julie A. Caswell

\begin{abstract}
Food product attributes related to geographical origins are a topical issue in global food trade. The provision of geographical labelling may occur through geographical indications under the mandated trade rules of the TRIPS Agreement, trademarks, or country-of-origin labelling. The overall effect of the expansion of geographical labelling on developing countries depends on a complex mix of market opportunities that may yield substantial benefits as well as implementation costs. Increasingly, the analysis of this overall effect will need to evaluate the joint impacts of different forms of geographical labelling on the market position of developing countries.
\end{abstract}

Keywords: developing countries, geographical labelling, international trade, TRIPS

Dr. Sven Anders, Assistant Professor, Department of Rural Economy, University of Alberta, Edmonton Alberta T6G 2H1, Canada; phone +1 780492 5453, fax +1 780492 0268, sven.anders@ualberta.ca.

Dr. Julie A. Caswell, Professor and Department Chair, Department of Resource Economics, University of Massachusetts Amherst, Amherst Massachusetts 01002, USA. 
The Benefits and Costs of Proliferation of Geographical Labelling for Developing Countries

\section{Introduction}

Labelling that communicates the origin of products is becoming more prominent as consumers are increasingly concerned about the quality, safety, environmental, and social attributes of the foods they consume (Krisoff et al., 2002). Taken in its broadest terms, geographic labelling ${ }^{1}$ communicates the sourcing of a product or attributes of the product within a defined geographical location. Three common types of geographical labelling are discussed in this paper:

i) geographical indications (GIs), which are a specific type of collective certification mark,

ii) trademarks, and the sub-categories of certification marks can collective certification marks others than GIs, and

iii) country-of-origin labelling (COOL).

In a globalized food system, all three forms of labelling can provide valuable, albeit different, information to consumers seeking to know about the geographical origins of foods. On the supply side, there may be considerable differences in the motivations of producers and countries in different parts of the world for using the three types of labelling.

Much of the literature on geographical labelling is focused on the WTO systems for geographical indications (GIs) and certification marks, and on disputes related to these alternative systems. GIs are favoured by a camp led by the European Union, while a second camp led by the United States favours certification marks. For example, existing studies discuss several avenues for the resolution of the GI dispute (Vincent, 2007; Evans and Blakeney, 2006; Josling, 2006; Fink and Maskus, 2006; Rangnekar, 2004; Addor and Grazioli, 2002). In contrast, relatively little economic research addresses the more general question of tradeoffs and complementarities between the three types of geographical labelling. 
Policy makers and producers in developing countries may have different motives from those of their counterparts in developed countries for promoting or opposing the use of geographical labelling (Grant, 2005; Downes, 2004; Juma, 1999). The objective of this paper is to examine the impacts of alternative types of geographical labelling systems on developing countries. We focus on the opportunities and threats policy makers in developing countries face as they strive to maximize the benefits from use of geographical labelling to their producers.

\section{Background}

Producers and governments in several countries have spurred the development of various marketing strategies based on geographical labelling as the origin of food has emerged as a new purchasing criterion in the eyes of consumers seeking reliable quality signals, This geographical labelling is evolving from a fairly limited intellectual property rights (IPR) category to a broader spectrum of labelling alternatives that are a critical topic in the current Doha Round trade negotiations and may have important implications for economic development. Addor and Grazioli (2002) and Josling (2006) provide overviews of origin labelling and detailed discussions of the major distinctions between GIs, origin-based certification marks, and COOL. Here we highlight features of different types of geographical labelling that are important to understanding the overall benefits and costs of such labelling for developing countries.

\section{Geographical Indications}

Geographical Indications (GIs) are the most prominent type of geographical labelling. GIs constitute a distinct category of collective certification marks that all producers of a particular product in a certain region are allowed to use if they meet standards. Producers outside this specific geographical region are prohibited from using the collective mark. GIs are defined in article 22(1) of the WTO’s 1995 TRIPS Agreement as “indications which identify a good as originating in the territory of a Member, or a region or locality in that territory, where a given 
quality, reputation or other characteristic of the good is essentially attributable to its geographical origin.” Amongst the most prominent examples of geographical indications are the European Union's (EU) protected designations of origin (PDO) and protected geographical indications (PGI). The EU's sui generis system offers exclusive production rights and considerable price premiums to producer groups that hold them.

Data show wide differences in countries' use of GIs as a means of protecting intellectual property (IP), promoting geographically distinct agricultural products, and providing consumer information. Out of a total of 771 registered GIs in 2007, developing countries account for only 11.5\% (GAINT, 2008).

Within the TRIPS area, the discussion about the "right" level of GI protection is mainly polarized between two opposing camps: those countries that support a broader multilateral protection of GIs, the "proponents," and those that oppose alterations to the existing regulation of GIs in TRIPS, namely the "opponents.” Contrary to what one might expect, members of the opposing camps do not break along the "North-South” divide. Table 1, adapted from Fink and Maskus (2006), shows countries with more and less ambitious approaches toward extending GI protection. Together with the EU several developing countries see themselves as having active interests in extending the protection of GIs through adaptation of the multilateral GI register and/or extension of a higher level of GI protection to other goods. The group with less interest in these extensions is often associated with the "New World", led by the United States and including several developing countries in the Western Hemisphere, as well as other countries.

The creation of a multilateral GI register is the least controversial issue in that it has an explicit negotiation mandate. However, a dispute has evolved between the camps on whether a multilateral GI registry should be voluntary or mandatory. Strong concerns are voiced by the “opponents” to the mandatory GI registration proposed by the EU. Critics argue that granting exclusive production rights to holders of GI names could create significant barriers to entry and/or force producers of similar though not identical goods out of a market. 
Table 1: Countries with More and Less Ambition towards Extended Multilateral GI Protection

\begin{tabular}{|l|l|l|}
\hline Issue & More ambitious are... & Less ambitious are... \\
\hline $\begin{array}{l}\text { Adaptation of } \\
\text { multilateral } \\
\text { GI register }\end{array}$ & $\begin{array}{l}\text { Bulgaria, European Union, Georgia, } \\
\text { Iceland, Mauritius, Moldova, Nigeria, } \\
\text { Romania, Sri Lanka, Switzerland, } \\
\text { Turkey }\end{array}$ & $\begin{array}{l}\text { Argentina, Australia, Canada, Chile, } \\
\text { Colombia, Costa Rica, Dominican } \\
\text { Republic, Ecuador, El Salvador, } \\
\text { Guatemala, Honduras, Japan, Mexico, } \\
\text { Namibia, New Zealand, Philippines, } \\
\text { Taiwan (China), United States }\end{array}$ \\
\hline $\begin{array}{l}\text { Extension of } \\
\text { higher level } \\
\text { GI protection } \\
\text { to other goods }\end{array}$ & $\begin{array}{l}\text { Bulgaria, Cuba, European Union, } \\
\text { Georgia, Guinea, Iceland, India, } \\
\text { Jamaica, Kenya, Kyrgyz Republic, } \\
\text { Liechtenstein, Macedonia, } \\
\text { Madagascar, Mauritius, Morocco, } \\
\text { Pakistan, Romania, Sri Lanka, } \\
\text { Switzerland, Thailand, Tunisia, } \\
\text { Turkey }\end{array}$ & $\begin{array}{l}\text { Ecuador, El Salvador, Guatemala, } \\
\text { Honduras, New Zealand, Panama, } \\
\text { Paraguay, Philippines, Taiwan } \\
\text { (China), United States }\end{array}$ \\
\end{tabular}

Source: Based on submissions of WTO members since 2001 (TN/IP/W/3, TN/IP/W/5, TN/ IP/W/10, and as summarized by the WTO Secretariat in Document TN/C/W/25). Adapted from Fink and Maskus (2006).

\section{Trademarks, Certification Marks, and Collective Marks}

Trademarks, and its subcategories of certification marks and collective marks, are a second category of geographical labelling, although not all of these marks carry a signal of geographical origin. GIs and trademarks serve the same underlying principles and face many of the same multilateral challenges, their relationship remains unresolved when surveyed at the international level. Both offer a way to reduce information asymmetries and search costs in markets; these asymmetries and costs can otherwise create significant inefficiencies or inhibit transactions in trade for higher quality food products. In addition, privately owned trademarks can act as the basis for the development of brands and quality reputations that consumers can use to distinguish between goods differentiated by origins.

There is a significant difference, however, in the public versus private signals that flow from these two types of geographical labelling. Geography is at the center of the publically regulated GIs and access is open to producers who can meet the GI standards. In contrast, the linkage between the proprietor of the trademark and its products is at the heart of trademarks, while the geographic link may be secondary. The complicated coexistence between registered GIs and 
privately owned trademarks is evident in the prominent disputes around Basmati rice, Darjeeling and Rooibos tea, and Ethiopian coffee beans. In these cases, the respective names are registered trademarks held by companies in countries other than the developing country claiming to be the geographical origin of the product.

The treatment of trademarks under TRIPS has received differential levels of attention in the economic literature. Baroncelli et al. (2005) and Fink and Smarzynska (2002) agree that filings of certification marks play an important role in the protection of intellectual property for specific geographic origins. However, as an indicator of their role in IP protection little is known about the global distribution and use of certification and collective marks in agriculture.

In contrast to the heated GI debate trademarks have a long history of use in protecting private IP and brand names, although mostly outside the agricultural sectors. Figure 1 shows levels of trademark registrations across all trademark categories and associated products by groups of WTO member countries and leading economies from 1975 to 2005. A preliminary search revealed that in 2005 roughly $8 \%$ of 2.43 million worldwide active trademarks are registered for food and agricultural products including meats (USPTO, 2007; WIPO, 2007).The distribution of trademark filings shows a similar pattern of imbalance in use as exists for GIs. Leading global economies and the fast growing economy of China clearly lead in trademark registrations. At the same time, many developing regions of the world (e.g., Africa, South East Asia, and the Middle East) lag behind in trademark filings, both in total numbers and growth over time. 
Figure 1: Development of Trademark Filings by World Regions and Leading Economies $1975-2005^{a}$

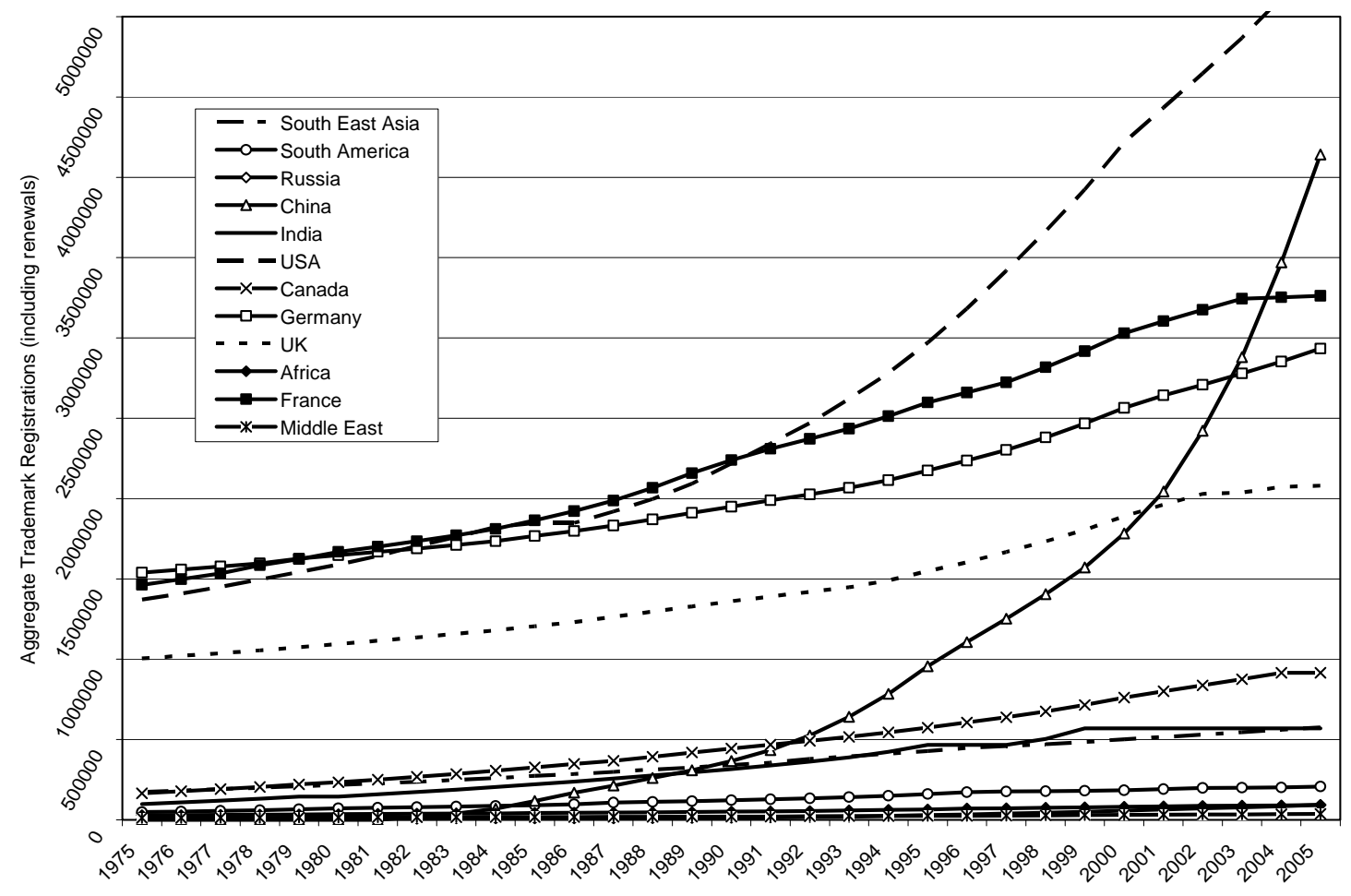

a) The data series represent numbers of cumulative domestic and foreign trademark registrations by WTO member countries. World region series were created by aggregating country level series.

Source: Authors' calculation based on WIPO (2007).

\section{Country-of-Origin Labelling}

The third major category of geographical labelling is country-of-origin labelling (COOL). It has received considerable attention around the world (U.S. GAO, 2003). COOL informs consumers about a product's national origin, which may be an important criterion in their purchase decisions (Loureiro and Umberger, 2005). While GIs and some certification marks link geographical origin with a certain and guaranteed product quality, COOL is solely linked to geographic origin. This makes COOL both the simplest and vaguest form of source identification. COOL has usually been treated and discussed separately from geographical indications. However, stricter enforcement of COOL requirements in countries adds an additional dimension to the debate over GIs and trademarks, especially certification marks, as well. 
In the United States, proponents of COOL highlight the "right” of consumers to know the origin of their food as a means of reducing concerns about quality, safety, and production methods. Many U.S. producer groups have endorsed COOL as a valuable marketing tool based on a positive country image that might give domestic farm produce an advantage over imports. However, much of the literature on the effects of mandatory COOL in the U.S. suggests that the costs of implementation for producers may very likely outweigh estimated consumer benefits (Lusk and Anderson, 2004; Brester et al., 2004).

Beyond cost-benefit analyses for the U.S., comparatively little attention has been devoted to the potential trade implications of mandatory COOL for developing countries. Compliance with COOL requirements may create a substantial cost barrier and competitive disadvantage for imported goods from developing country suppliers. In addition, as discussed below, COOL could overshadow and even negate the quality-origin claims conveyed by GIs and trademarks.

\section{How the Expansion of Geographical Labelling May Affect Developing Countries}

The overall economic impact of globalization for developing countries has been evaluated as mixed so far (Baddeley, 2006). Increases in international trade flows have been paralleled by an economic convergence of countries into clubs, leaving a significant portion of the developing world behind. Empirical evidence by Sala-I-Martin (2006) suggests that welfare improvements from globalization are significant for South and East Asia but have not reduced poverty in SubSaharan Africa. Through a more active participation in the current Doha Round, and TRIPS negotiations in particular, developing countries are striving to add authority to their quest for greater equality in global food trade.

For example, an overall reason for developing countries to favour the extension of multilateral geographical indications (GIs) protection is to avoid the misappropriation of terms describing products in which they have a particular commercial, traditional, or national interest. It remains an open question, however, whether, and to what extent, proliferation of geographical 
labelling (better protection of geographical indications; increased use of trademarks of various types; and wider use of COOL) will achieve the outcomes sought by policy markers and producers in developing countries of supporting domestic production and exports.

Studies that address the harmonization of IP protection for geographical labelling show that all three regulatory systems, GIs, trademarks, and COOL, create non-tariff trade barriers (Josling, 2006; Grant, 2005; Fink and Smarzynska, 2002; Williams, 2002). To date, the effects of nontariff barriers on the trade relations of developing countries have been most fully analysed for the WTO Agreement on the Application of Sanitary and Phytosanitary Measures (SPS Agreement). The literature is in dispute with regard to the implications of SPS measures on agricultural exports from developing countries (Anders and Caswell, 2007; Henson and Jaffee, 2006; Josling et al., 2004). Here we explore four major issues that affect the likely balance of benefits and costs from geographical labelling for developing countries.

First, the major argument for consumers to favour geographical labelling is that it provides information on a product's origin and quality and this information is effective in mitigating quality uncertainty. Loureiro and Umberger (2005) explicitly emphasize that European consumers’ willingness-to-pay for specific geographical origins is closely linked to a positive eating experience and high product quality. Hence, “origin” adds extra value to Italian Parmesan, French Champagne, and Portuguese Sherry as these products carry a portfolio of certified quality attributes, including food safety and consistent store availability. However, many or most foods from developing countries do not have the cachet and certified supply chain systems that European geographical indications (PDOs and PGIs) can bank on.

Second, the majority of policy makers in developing countries have no or limited experience in the use of the most demanding form of geographical labelling, geographical indications, as a policy tool. A broader protection of GIs at the international level may create yet another strong obligation for developing countries to invest scarce resources in establishing national GI frameworks. But chasing the dream of price premiums for protected and origin-labelled products 
may prove costly. This burden may increase if the scope of GI protection is expanded. For example, Grant (2005) found that the administrative and financial burden associated with the creation, implementation, and transnational enforcement of a mandatory multilateral GI register would require significant resources from developing countries.

Third, there is a range of challenges facing producers in developing countries in using GIs. Rangnekar (2004) points out that developing country producers pursuing traditional production methods under GIs might face unforeseen costs. Supply chain adjustments, new and added quality assurance schemes, and record keeping could result in prohibitively high costs for protecting GIs. These costs would need to be subtracted from the anticipated benefits of GI labelled products. Echols (2003) states that obligations from a GI system could lead to additional overhead production costs comparable to those associated with international food safety regulations.

In a case study for South Africa, Bramley and Kirsten (2007) find a strong economic rational for producers to protect GIs. Although they might provide a unique opportunity for market development in South Africa, the authors state that the economic premiums for GIs could be marginal. Confusion already exists among consumers about the relation between geographical origin and quality given the multitude of existing GI labels in Europe and certification marks in the U.S. (Marette et al., 2007). Thus, considerable market risk exists for new launches of geographical origin labels by developing countries. Finally, most resources have to be invested prior to the launch of GI labels without assurance of rewards.

Considering the stringency of a publicly regulated GI system à la the EU, an alternative consistent regulation of geographical labelling within the trademark system may constitute a more feasible and market-based option for policy markers and producers in developing countries. According to Bramley and Kirsten (2007), cost hurdles related to product registrations and period renewals in multiple markets in an alternative certification mark system could be prohibitive for resource poor producers. Irrespective of the type of protection, costly promotional efforts are 
required to convince consumers, at home and abroad, of origin-quality credentials that justify price premiums for GI or trademarked products.

Fourth, the existence of mandatory COOL requirements in the U.S. and elsewhere may have significant implications for the use of GIs and trademarks. COOL may complement or be superfluous to other forms of geographical labelling that are strong market signals of origin and quality. However, COOL as a market signal may substitute for and potentially swamp other forms of geographical labelling in cases where they provide weak signals on origin and quality. Recent cases of contaminated food ingredients and product recalls for Chinese products have shown that food safety incidents linked to a country of origin can result in overall negative notions of a country's product quality and cause detrimental effects on its trade relations.

As with other forms of labelling, compliance with COOL may create substantial cost barriers for developing country suppliers who lack the record-keeping infrastructure to maintain audit requirements (Chambolle and Giraud-Heraud, 2005). Studies that investigate the implications of increasing food safety requirements (e.g., HACCP) for developing countries suggest the overall trade effects have been mixed. However, empirical evidence suggests that many small scale developing country exporters are made worse off (Anders and Caswell, 2007; Henson and Jaffee, 2006).

The overall effect of the expansion of geographical labelling on developing countries depends on a complex mix of market opportunities that may yield substantial benefits and on the costs of implementing different systems of labelling. Increasingly, the analysis of this overall effect will need to evaluate the joint impacts of different forms of geographical labelling on the market position of developing countries. To date, the most comprehensive analysis available is for the class of geographical indications under the WTO. 


\section{Regulatory Issues for Developing Countries in Implementing Geographical Indications}

In order to attain consistent implementation of geographical origin rules, the WTO required members to bring their national legal systems for IPR protection into accordance with the TRIPS agreement (TRIPS, Article 22, 2). This implementation for developing countries has been supported by extended adjustment periods and calls for technology transfer, regulatory assistance, and technological and financial cooperation from developed countries. Since the success of any new GI policy framework in many developing countries will depend at least in part on the extent of technical, financial, and regulatory assistance from developed WTO members, the elimination of major inequalities in the future regulation of geographical origin labelling will not happen automatically (Evans and Blakeney, 2006).

Two other major regulatory issues have arisen for developing countries in close relation to GI implementation. The first is in regard to the exemption clause in TRIPS Article 24, which explicitly regulates "generics.” These are products that a priori do not qualify for GI protection because their names have evolved into generic expressions (e.g., Basmati rice). The exemption of generic terms from GI protection has led to 175 bilateral agreements that regulate specific GIs apart from existing certification marks. In some cases these go beyond the current status of GI protection under TRIPS.

The EU and the United States both seek to promote their regulatory version of a GI protection system in order to incur minimum adjustment costs and pursue their best economic strategies. Hence, bilateral agreements emerge as an additional commitment for developing countries. They also create restrictions that reduce the options for convergence of approaches on the GI issue in the interest of developing countries (Vivas-Eugui and Spennemann, 2006). As a result, developing country policy makers need particularly to scrutinize bilateral agreements related to GI labelling for their conformity with their economic and societal priorities and coherence with other existing obligations in order to avoid unnecessary burdens for their producers. 
A second major regulatory issue for developing countries arising out of GI implementation is the process of claiming rights for new GIs. Unlike certification marks, whose creation as private IP can create valuable brand recognition for the IP owner that is transferable, the exclusiveness and perpetuity of producer rights conveyed by GIs is quite constrictive. Any producer group aiming for multilateral recognition of a new GI bears the burden of proof, including all necessary expenses for full compliance with TRIPS requirements. This involves being able to prove at all times that the product's quality is fully attributable to its origin. Moreover, producers-with the assistance of their government—must provide sufficient evidence of the GI's long standing reputation in the respective domestic market that would justify GI status. These requirements can clearly limit the possibilities for developing countries to create new GI labels that have a strong market identity and helps to explain why trademarks are distributed across a much broader country base (as seen in Figure 1) (Baroncelli et al., 2005).

Fink and Smarzynska (2002) suggest that the main hurdle for many developing countries is that GIs have to be protected domestically before they can be registered at the international level. This is in contrast to the situation in the EU, which originated the GI concept and has large, established, commercial interests in assuring exclusive production rights. The same regulatory circumstances for international GIs do not exist in many developing economies. This poses an immediate disadvantage to those countries that already lag behind in the adoption of other international trade standards, such as food safety and technical trade regulation (Anders and Caswell, 2007).

\section{Market Access and Trade Impacts for Geographical Indications}

Several countries, many of them commodity exporters and/or “New World” countries, have argued that GIs are inherently trade restrictive and have the potential to create non-tariff trade barriers. In fact, the current TRIPS protocol does not prevent the risk of misuse of GIs. Accusations led by the United States and Australia of discriminatory treatment by the European 
Union of foreign GIs and certification marks resulted in a call for a WTO dispute settlement panel (Evans and Blakeney, 2006). As a result of consultations, the EU has simplified its registration requirements for foreign GIs through amendment 510/2006 to EU regulation 2081/92. Regulation EU 510/2006 provides greater equivalence and reciprocity for products from third countries, granting easier market access and protection of GIs within the EU. This outcome may be particularly relevant for a number of developing countries producing traditional goods that might qualify as PDOs or PGIs.

Given the diversity of agricultural production in the developing world, increasing investments in GIs may not always or frequently result in additional export revenues. Nor would better domestic GI policies guarantee developing countries their strived for better access to highvalue export markets. In addition, there is some reason to believe that greater investment in GI protection by developing countries has poor prospects as long as the existing challenge of compliance with technical regulations and trade standards has not yet been successfully met.

Supply chain structures are a particular concern of policy makers related to market access and the trade impact of GIs. The lack of sophisticated supply chain structures common to products such as Gorgonzola cheese, Bordeaux wine, and Parma ham in Europe lessen the prospects of successful marketing of GI brands by developing economies. Well organized supply chain strategies, promotion, and marketing systems for specialities like "Basmati rice,” “Ethiopian coffee,” or "Rooibos tea” are seen as a prerequisite for the successful marketing of GI products. To date the only foreign GI that has been registered within the EU is “Café de Colombia” (EU 510/2006). While Colombia had the financial and technical expertise to register and take advantage of its café PDO in the EU, many poorer countries that lack the necessary resources have not been able to achieve revenues from trade in their GI products.

In addition, it remains unclear how the marketing of potential GI products from developing countries will be affected by the specific demands of intermediaries, such as global retail chains. Given the high priority consumers in western economies place on food standards, it is unlikely 
that retailers in Europe or North America will waive existing requirements above and beyond regulatory requirements in favour of GIs from the developing world. Moreover, retail market power could deprive developing country producers of the benefits of GI labelling. For example, when Ethiopia's coffee producers attempted to obtain certification marks for the region where its famous coffee is grown producers had to contend with the global coffee giant Starbucks, which claimed property rights to use the geographical name (Adamy, 2007; Patrick, 2008).

A more equal and open multilateral system for GI protection may provide easier access to consumers in high-value markets. Once regulatory certainty is guaranteed producer groups in developing countries may find it easier to raise the necessary financial resources to invest in private certification marks to secure the IP associated with traditional speciality food products.

\section{Conclusions}

Many countries, and producers and companies within them, are making broader use of different types of geographical labelling, including geographical indications, trademarks, and country-oforigin labelling. A broader range of such labelling, supported in many cases by broader multilateral regulation and oversight, offers new opportunities for the protection of intellectual property rights and for the remunerate marketing of traditional or unique food products. However, taking advantage of these opportunities requires incurring costs.

From a developing country perspective, a broader sui generis protection of GIs á la the EU may create new barriers to trade due to standards and regulatory requirements in an otherwise increasingly open trading system. For example, India has a substantial interest in dairy exports given its strong dairy sector. Under future sui generis GI rules, India’s dairy sector would lose the right to export its version of Mozzarella cheese, which to date it does successfully (Williams, 2002). At the same time, it might gain the exclusive rights for Basmati rice. In light of the diverse production portfolios held by many developing countries, they could not be assured of greater gains than losses from expanded GI regulation under TRIPS. 
More generally, it is important to consider the overall impact of geographic labelling of all types on competition for market position in international trade by developing countries. GIs may have potential for supporting the export growth of some countries or regions and trademarks likely provide a similar growth potential. However, the successful participation of developing countries in the current debate regarding systems for GIs and trademarks of various types may be insufficient for developing economies to achieve their expectations for benefits from such IP protection. Net benefits depend of the cost of participating in this type of marketing and the competitive environment.

Among different types of geographical labelling, the debate on geographical indications has garnered the most attention in international circles. For a full perspective, this debate needs to be embedded in the context of the broader range of geographic labelling that affects the ability of countries to operate successfully in international markets. For example, COOL may be a complement or substitute to the signals conveyed by geographical identifications or trademarks of various types. When quality or safety problems emerge, they may be attributed to a broad range of products from a country or affect an entire country's reputation rather than that of a particular supply chain. In these cases, consumers' negative awareness of origin based on COOL may swamp the positive marketing effects created by GIs or trademarks. Overall, demand for products with a certain country of origin may decline as consumers are able to identify and avoid products “made in X."

Further empirical evidence is needed to evaluate the benefits and costs of geographical labelling for developing countries. For example, when problems occur do GI supply chains have strong enough independent reputations to withstand negative spill over effects from COOL? Ultimately, the success of geographical labelling as a tool for greater equality in international trade and for the protection of traditional knowledge will be determined by the interplay of the effects of different types of labelling on market shares, price premiums, and the longevity of geographical brand names. 


\section{References}

Adamy, J. 2007. Starbucks nears Deal with Ethiopia. Wall Street Journal, 05/04/2007, p. B3.

Addor, F. and A. Grazioli. 2002. Geographical Indications beyond Wines and Spirits. A Roadmap for a Better Protection for Geographical Indications in the WTO/ TRIPS agreement. The Journal of World Intellectual Property, 5(6): 865-897.

Anders, S. and J.A. Caswell. 2007. Standards-as-Barriers versus Standards-as-Catalysts: Assessing the Impact of HACCP Implementation on U.S. Seafood Imports. ResEc Working Paper 2007-7, University of Massachusetts Amherst, Department of Resource Economics, MA, USA, $41 \mathrm{p}$.

Baddeley, M. 2006. Convergence or Divergence? The Impacts of Globalisation on Growth and Inequality in Less Developed Countries, International Review of Applied Economics, 20(3): 391-410.

Baroncelli, E., C. Fink and B. Smarzynska. 2005. The Global Distribution of Trademarks: some Stylized Facts. The World Economy, 28: 765-782.

Bramley, S. and J.F. Kirsten. 2007. Exploring the Economic Rationale for Protecting Geographical Indicators in Agriculture. Agrekon, 46(1): 69-93.

Brester, G.W., J.M. Marsh and J.A. Atwood. 2004. Distributional Impacts of Country-of-Origin Labelling in the U.S. Meat Industry. Journal of Agricultural and Resource Economics, 29(2): 206-227.

Chambolle, C. and E. Giraud-Héraud. 2005. Certification of Origin as a non Tariff Barrier. Review of International Economics, 13(3): 461-471.

Commission of the European Union. 1992. Council Regulation (EEC) No. 2081/92 of July $14^{\text {th }}$ 1992 on the Protection of Geographical Indications and Designations of Origin for Agricultural Products and Foodstuffs. Official Journal of the European Communities, L208, 24/07, pp. 1-8. 
Downes, G. 2004. TRIPs and food security Implications of the WTO’s TRIPs Agreement for food security in the developing world. British Food Journal, 106(5): 366-379.

Echols, M.A. 2003 Geographical Indications for Foods, TRIPS and the DOHA Development Agenda. Journal of African Law, 47(2): 199-220.

Evans, G.E. and M. Blakeney. 2006. The Protection of Geographical Indications after Doha: Quo Vadis? Journal of International Economic Law, 9: 575-614.

Fink, C. and K. Maskus. 2006. The Debate on Geographical Indications in the WTO. In: Trade, Doha, and Development: A Window into the Issues. Newfarmer, R. (ed.), Washington, D.C.: World Bank, pp. 197-207.

Fink, C. and B. Smarzynska. 2002. Trademarks, Geographical Indications, and Developing Countries. In: Development, Trade, and the WTO: A Handbook (ed.) Hoekman, B., A. Mattoo and P. English, Washington, DC, World Bank, pp. 403-441.

Geographical Indications \& International Trade (GAINT). Data and Information, Resources: A Global GI Database. Available at: www. www.american.edu/ted/giant/ resources2.html. Access on April 29, 2008.

Grant, C. 2005. Geographical Indications: Implications for Africa. Trade Law Centre for Southern Africa (tralac), Trade Brief No. 6/2005, November 2005, 15 p.

Henson, S. and S. Jaffee. 2006. Food Safety Standards and Trade: Enhancing Competitiveness and Avoiding Exclusion of Developing Countries. European Journal of Development Research, 18(4): 593-621.

Josling, T., D. Roberts and D. Orden. 2004. Food regulation and trade: Toward a safe and open global system. Institute for International Economics 203, Washington D.C., 14 p.

Josling, T. 2006. The War on Terroir: Geographical Indications as a Transatlantic Trade Conflict. Journal of Agricultural Economics, 57(3): 337-363. 
Juma, C. 1999. Intellectual Property Rights and Globalization: Impacts for Developing Countries. Science, Technology and Innovation Discussion Paper No. 4, Center for International Development, Harvard University, Cambridge, MA, USA, 22 p.

Krisoff, B., M. Bohman and J.A. Caswell (ed.). 2002. Global food trade and consumer demand for quality. New York, Dordrecht and London: Kluwer Academic/Plenum, 251 p.

Loureiro, M.L. and W.J. Umberger. 2005. Assessing Consumer Preferences for Country-ofOrigin Labelling. Journal of Agricultural and Applied Economics, 37(1): 49-63.

Lusk, J.L. and J.D. Anderson. 2004. Effects of Country-of-Origin Labelling on Meat Producers and Consumers. Journal of Agricultural and Resource Economics, 29(2): 185-205.

Marette, S., R. Clemens and B.A. Babcock. 2007. The Recent International and Regulatory Decisions about Geographical Indications. Working Paper 07-MWP 10, Midwest Agribusiness Trade Research and Information Center (MATRIC), Iowa State University, Ames, Iowa, USA, 35 p.

Patrick, Aaron O. 2008. Ethiopia Puts Logo on Its Hottest Export. Wall Street Journal, May 15, p. B7.

Rangnekar, D. 2004. The Socio-Economics of Geographical Indications. A Review of Empirical Evidence from Europe. UNCTAD-ICTSD Project on IPRs and Sustainable Development, Issue Paper No. 8, ICTSD and UNCTAD, 2004, 46 p.

Sala-I-Martin, X. 2006. The World Distribution of Income: Falling Poverty and... Convergence, Period. Quarterly Journal of Economics, 121 (2) 351-379.

United States General Accounting Office (U.S. GAO). 2003. Country-of-Origin Labelling: Opportunities for USDA and Industry to Implement Challenging Aspects of the New Law. Washington, D.C.: United States General Accounting Office, 60 p.

U.S. Patent and Trademark Office (USPTO). 2007. Trademark Electronic Search System (TESS). Accessed on July $15^{\text {th }} 2007$. 
Vincent, M. 2007. Extending Protection at the WTO to Products Other Than Wines and Spirits: Who Will Benefit? The Estey Centre Journal of International Law and Trade Policy. 8(1): 58-69.

Vivas-Eugui, D. and C. Spennemann. 2006. The Treatment of Geographical Indications in Recent Regional and Bilateral Free Trade Agreements. International Centre for Trade and Sustainable Development (ICTSD), Project on Intellectual Property and Sustainable Development, ICTSD, Geneva, Switzerland, 29 p.

Williams, D. 2002. Extension of Stronger Geographical Indications Protection: Against the Interests of Developing Countries? Bridges, 6(4): 17-20.

World Intellectual Property Organization (WIPO). 2007. Statistics on Trademarks. Available at: www.wipo.int/ipstats/en/statistics/marks/. Accessed on: July $10^{\text {th }} 2007$.

World Trade Organization (WTO). Agreement on Trade-Related Aspects of Intellectual Property Rights (TRIPS). Available at: www.wto.org/english/tratop_e/trips_e/t_agm0_e.htm. Accessed on July $22^{\text {nd }} 2007$.

World Trade Organization (WTO). 2005. Poorest countries given more time to apply intellectual property rules. WTO Press Release $424,29^{\text {th }}$ Nov. 2005. Available at: www.two.org/english/news_e/press05_3/pr424_e.htm. Accessed on July $13^{\text {th }} 2007$.

\section{Endnotes}

1 'Geographical indicators' is another overall term used to describe different types of origin labelling. We use the term 'geographical labelling' as the generic term for these types of information signals in order to avoid confusion between geographical indicators and geographical indications, which are a specific type of indicator. We recognize that geographic labelling does not always include consumer labelling. 